\title{
E-cadherin expression and prognosis of head and neck squamous cell carcinoma: evidence from 19 published investigations
}

This article was published in the following Dove Press journal:

OncoTargets and Therapy

26 April 2016

Number of times this article has been viewed

\author{
Xusheng Ren ${ }^{1,2}$ \\ Jianning Wang ${ }^{2}$ \\ Xuefen $\operatorname{Lin}^{1,3}$ \\ Xuxia Wang ${ }^{1,3}$
}

'Department of Oral and Maxillofacial Surgery, Stomatological Hospital of Shandong University, ${ }^{2}$ Department of Oral and Maxillofacial Surgery, Jinan Stomatological Hospital, ${ }^{3}$ Shandong Province Key Laboratory of Oral Tissue Regeneration, Stomatological Hospital of Shandong University, Jinan, Shandong Province, People's Republic of China
Correspondence: Xuxia Wang Stomatological Hospital of Shandong University, No 44 Wen Hua Xi Lu Road, Jinan 2500 I2, Shandong Province, People's Republic of China Email wxx@sdu.edu.cn
Objective: The objective of this study was to review the published literature and investigate whether E-cadherin gene is a prognostic factor in head and neck squamous cell carcinoma by conducting a meta-analysis.

Methods: Studies were identified from the databases Embase, Medline, and Cochrane Library by using the keywords "E-cadherin gene" and "head and neck cancer". Overall survival (OS) and disease-free survival (DFS) were the primary outcome measurements.

Results: Our literature review identified 1,458 articles; 19 studies with a total number of 2,012 cases were eligible for inclusion in the meta-analysis. The hazard ratio (HR) for OS of patients with decreased expression of E-cadherin gene was $0.57(95 \% \mathrm{CI}=0.37,0.89 ; P=0.000)$. However, statistical heterogeneity was unacceptably high $\left(I^{2}=74.5 \%, P=0.000\right)$. After sensitivity analysis, heterogeneity became acceptable, and the effect measure was still significant $(R=7.0 \%$; HR $=0.52$; $95 \% \mathrm{CI}=0.40,0.66 ; P=0.000)$. The HR for DFS was $0.53(95 \% \mathrm{CI}=0.42,0.67 ; P=0.000)$.

Conclusion: This meta-analysis showed clear evidence that high E-cadherin gene expression is a positive prognostic factor of head and neck squamous cell carcinoma, resulting in better OS and DFS. However, this conclusion must be interpreted with caution due to a few limitations.

Keywords: E-cadherin gene, prognosis, head and neck squamous cell carcinoma, immunohistochemistry

\section{Introduction}

Head and neck squamous cell carcinoma (HNSCC) is the most common cancer in the world and accounts for $\sim 3 \%$ of all cancer cases. ${ }^{1,2}$ Although significant advancements have been made in prevention, diagnostics, and treatment strategies for HNSCC, the survival rates in patients with progressive or metastatic disease have remained poor over the last 20 years. $^{3-5}$ Prognostic markers remain the basis for early detection and accurate survival evaluation for oral squamous cell carcinoma patients.

Numerous studies suggest that E-cadherin gene is a predictor of oral squamous cell carcinoma prognosis. ${ }^{6-24}$ E-cadherin is a $120 \mathrm{kDa}$ transmembrane glycoprotein that mediates homotypic $\mathrm{Ca}^{2+}$-dependent intercellular adhesion in dissimilar epithelia. Moreover, E-cadherin is a pivotal factor for managing cell-to-cell adhesion in epithelial tissues. ${ }^{25}$ At present, downregulation or aberrant expression of E-cadherin gene is associated with cancer invasion and poor prognosis in various carcinomas, including HNSCC. In addition, a multitude of existing studies have investigated the effect of E-cadherin gene on prognosis in HNSCC. However, E-cadherin gene has no consistent prognostic value for HNSCC. Additionally, most of the published literature includes 
studies that are small in size,,$^{8,18-20}$ heterogeneous, ${ }^{14,19,22}$ and conflicting in their results. ${ }^{17,19,22,23}$ Thus, we performed a metaanalysis to systematically estimate the value of E-cadherin gene as a prognostic factor in HNSCC.

\section{Methods}

\section{Literature search}

A literature search was performed using Embase, Medline, and Cochrane Library. The database was searched with the following keywords (and/or MeSH words): E-cadherin gene, tongue cancer (squamous cell carcinoma), buccal cancer (squamous cell carcinoma), oral cancer (squamous cell carcinoma), mouth cancer (squamous cell carcinoma), tonsil cancer (squamous cell carcinoma), oropharynx cancer (squamous cell carcinoma), hypopharynx cancer (squamous cell carcinoma), nasopharynx cancer (squamous cell carcinoma), larynx cancer (squamous cell carcinoma), neck cancer (squamous cell carcinoma), and head and neck cancer (squamous cell carcinoma). Reference lists within the relevant articles were used as potentially eligible sources.

\section{Inclusion criteria}

Studies were included if they met all the following inclusion criteria: a) patients were diagnosed with HNSCC and biopsy confirmed (no age limit); b) focused on the evaluation of E-cadherin gene expression in primary tumor and the correlation between E-cadherin gene expression and survival outcomes; and c) outcome indicators included overall survival (OS) or disease-free survival (DFS).

\section{Exclusion criteria}

Studies were excluded if they met any of the following exclusion criteria: a) no clear follow-up and survival analysis or could not provide sufficient data required for prognostic estimation of patients; b) no use of immunohistochemistry to assess the expression of E-cadherin gene; c) case reports, comments, letters to the author, reviews, and meta-analyses; and d) were not written in English.

\section{Quality assessment and data analysis}

The quality and risk of bias of all the included trials were assessed independently by two reviewers, Xusheng Ren and Jianning Wang, based on the Cochrane Handbook for Systematic Reviews of Interventions. Assessment of risk of bias was evaluated as "low risk of bias," "unclear risk of bias," or "high risk of bias" in each part, with notes explaining the specific reasons for each assessment in the risk of bias table. Any contradictions in opinion were resolved by discussion.
We extracted data from the eligible studies using an extraction form (Review Manager 5.3). We attempted to contact study authors for relevant missing or unclear data. We also attempted to contact the authors to confirm whether the study was duplicated or if there was any doubt whether the studies shared the same patients. We excluded studies that did not meet the inclusion criteria in terms of study design. One reviewer extracted the data, which was checked by another reviewer, and all conflicts were resolved by discussion.

\section{Statistical analysis}

All individual outcomes were pooled using Stata 12.0. The hazard ratio (HR) and its $95 \%$ confidence interval (CI) were used for meta-analysis of OS or DFS. We performed a random-effects model to merge HR when the heterogeneity was acceptable $\left(I^{2}<50 \%\right)$ and a fixed-effects model when the heterogeneity was unacceptable $\left(I^{2} \geq 50 \%\right)$. Statistical heterogeneity, which is the variation in results between studies, was assessed using the chi-square distributed Q statistic. Subgroup analyses and sensitivity analyses were performed when the heterogeneity was unacceptable.

\section{Results Search findings}

Our literature review identified 1,458 articles, including 1,385 articles from Medline, Embase, and Cochrane Library and 73 articles from the reference lists of articles obtained. A total of 1,410 articles were excluded after reviewing the titles and abstracts. The remaining 48 articles were further evaluated for eligibility and another 29 articles were eventually excluded. Figure 1 shows the flowchart of literature retrieval and lists the reasons for their exclusion. Nineteen studies with a total number of 2,012 cases were eligible for inclusion in the meta-analysis. Seven studies had data for both OS and DFS, nine studies had data only for OS, and three studies had data only for DFS. We could get all the needed data from these 19 studies and did not need to contact the authors.

\section{Study characteristics and treatment}

As shown in Table 1, in these 19 studies, there were ten studies $6,10,12,16,17,19,20,22-24$ that reported only using surgery. Six studies $8,9,11,13,15,18$ reported that all the patients were treated with surgery and some patients were treated with radiotherapy. Two studies ${ }^{7,13}$ reported that all the patients were treated with surgery and some patients were treated with radiotherapy and/or chemotherapy. Only one study ${ }^{20}$ reported that all the patients were treated with surgery and some patients were treated with chemotherapy. 


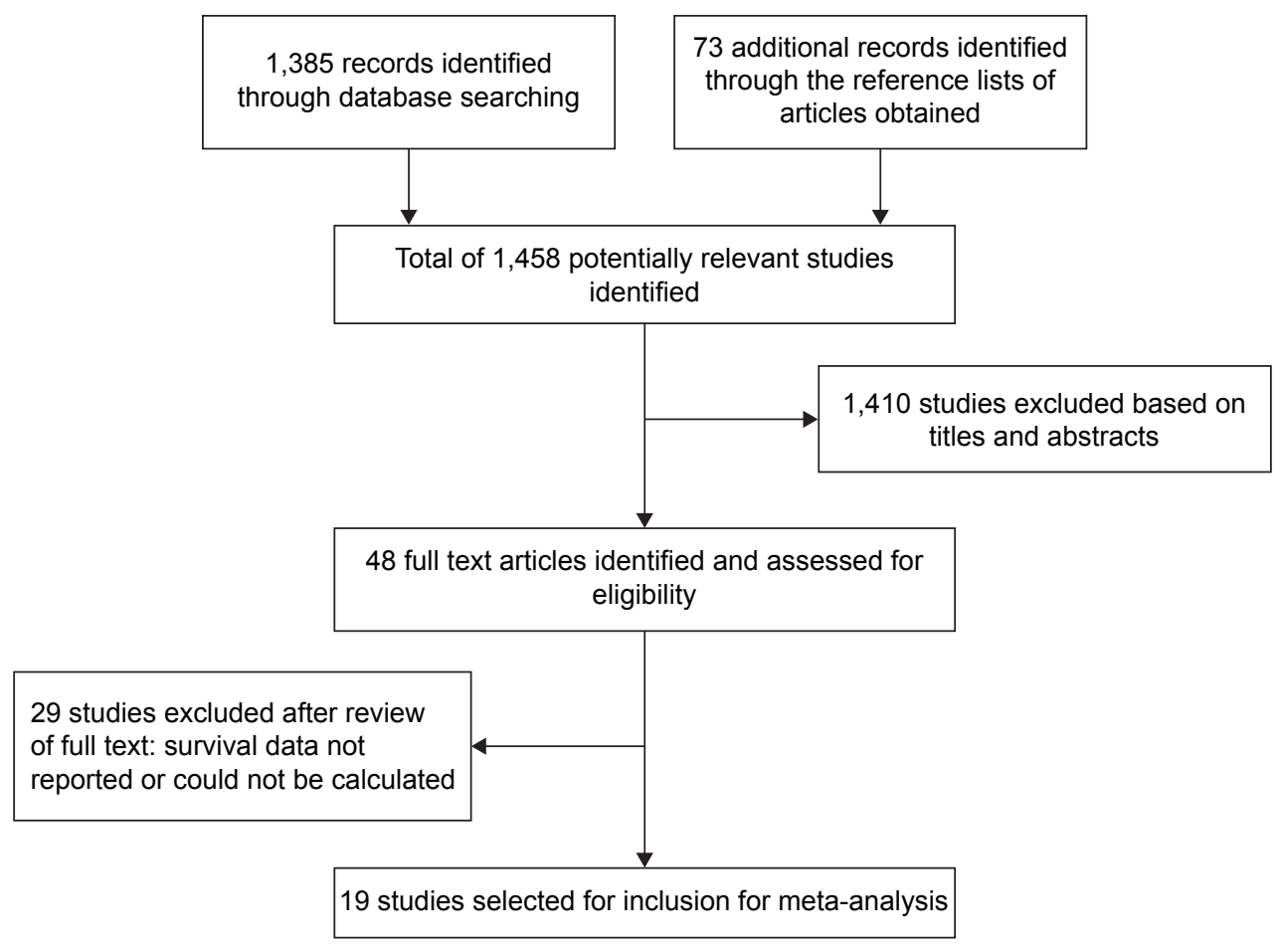

Figure I A flow diagram of literature search.

\section{Methodology assessment of E-cadherin gene expression}

The detection method of E-cadherin gene was immunohistochemistry, and all studies except the study by Psyrri et al ${ }^{9}$ provided immunohistochemistry staining figures.

\section{Meta-analysis}

\section{E-cadherin gene expression and OS}

In this meta-analysis, there were seven studies ${ }^{7,9,10,19,20,23,24}$ that provided HR values and $95 \% \mathrm{CI}$. Therefore, we directly utilized them for the evaluation of E-cadherin gene expression and OS. There were another nine studies ${ }^{6,8,12-18}$ from which the HR values and their corresponding 95\% CI could be calculated according to the data provided by the investigators. ${ }^{26}$ There was significant heterogeneity between each study $\left(I^{2}=74.5 \%, P=0.000\right)$. The HR for OS was 0.57 ( $95 \%$ $\mathrm{CI}=0.37,0.89 ; P=0.000)$. However, statistical heterogeneity was unacceptably high, driven by one study. ${ }^{22}$ When this study was excluded, heterogeneity became acceptable, and the effect measure was still significant $\left(I^{2}=7.0 \%\right.$; HR $=0.52$; $95 \% \mathrm{CI}=0.40,0.66 ; P=0.000$; Figure 2 ).

\section{E-cadherin gene expression and DFS}

In this meta-analysis, there were five studies ${ }^{7,9,11,15,21}$ that provided HR values and $95 \% \mathrm{CI}$. Therefore, we directly utilized them for the evaluation of E-cadherin gene expression and DFS. There were another five studies ${ }^{12,13,17,18,20}$ from which the HR values and their corresponding 95\% CI could be calculated according to the data provided by the authors. There was no significant heterogeneity between each study $\left(I^{2}=0.0 \%, P=0.860\right)$. The HR for DFS was $0.53(95 \%$ $\mathrm{CI}=0.42,0.67 ; P=0.000$; Figure 3 ).

\section{Publication bias analysis}

Publication bias of this meta-analysis was analyzed by the use of Stata 12.0 software. According to the funnel plots (Figures 4 and 5), there was an asymmetry, either visually or from Begg's test (OS: $P=0.753$; DFS: $P=0.210$ ). This indicates that there was no obvious publication bias and the result of the study was stable and credible.

\section{Discussion}

Numerous studies have reported that E-cadherin gene is a predictor for cancer prognosis. ${ }^{27-30}$ The low expression of E-cadherin gene is a characteristic of loss of epithelial cell adhesion, which has been correlated with the phenotypic changes of increased invasiveness and motility of cancer cells. Some studies have shown that high expression of E-cadherin gene is associated with good prognosis in many epithelial cancers. ${ }^{29,30}$ However, the prognostic value of E-cadherin gene in patients with HNSCC is still controversial. Some studies $^{8,10,15,23}$ report that high E-cadherin gene expression is 
Table I The features of included studies

\begin{tabular}{|c|c|c|c|c|c|c|c|}
\hline Author & Year & Country & $\begin{array}{l}\text { Size of } \\
\text { study }\end{array}$ & Tumor locations & $\begin{array}{l}\text { Tumor } \\
\text { stage }\end{array}$ & Treatment & $\begin{array}{l}\text { Data of } \\
\text { OS or DFS }\end{array}$ \\
\hline da Silva et a ${ }^{6}$ & 2015 & Brazil & 102 & OscC & I-IV & Surgery & OS (DSS) \\
\hline Ahmed et $\mathrm{al}^{7}$ & 2014 & Egypt & 75 & LSCC & I-IV & $\begin{array}{l}\text { Surgery, radiotherapy, } \\
\text { and chemotherapy }\end{array}$ & OS and DFS \\
\hline Pectasides et $\mathrm{al}^{8}$ & 2014 & USA & 67 & HNSCC & I-IV & $\begin{array}{l}\text { Surgery and } \\
\text { radiotherapy }\end{array}$ & DFS (PFS) \\
\hline Psyrri et al ${ }^{9}$ & 2014 & Greece & 289 & LSCC & $\mathrm{I}-\mathrm{IVa}$ & $\begin{array}{l}\text { Surgery and } \\
\text { radiotherapy }\end{array}$ & OS and DFS \\
\hline Fan et $\mathrm{al}^{10}$ & 2013 & Taiwan & 112 & Oscc & In situ-IV & Surgery & OS \\
\hline Kaur et al" & 2013 & India & 72 & Oscc & $\mathrm{I}-\mathrm{IVa}$ & $\begin{array}{l}\text { Surgery and } \\
\text { radiotherapy }\end{array}$ & DFS \\
\hline Imajyo et $\mathrm{al}^{12}$ & 2012 & Japan & 152 & OSCC & NA & Surgery & OS and DFS \\
\hline Li et al ${ }^{13}$ & 2012 & $\begin{array}{l}\text { People's Republic } \\
\text { of China }\end{array}$ & 64 & LSCC & I-IV & $\begin{array}{l}\text { Surgery and } \\
\text { radiotherapy }\end{array}$ & OS and DFS \\
\hline Ukpo et $\mathrm{al}^{14}$ & 2012 & USA & 154 & Oropharyngeal SCC & I-IV & $\begin{array}{l}\text { Surgery, radiotherapy, } \\
\text { and chemotherapy }\end{array}$ & OS \\
\hline Zhao et al ${ }^{15}$ & 2012 & $\begin{array}{l}\text { People's Republic } \\
\text { of China }\end{array}$ & 98 & Oscc & I-IV & $\begin{array}{l}\text { Surgery and } \\
\text { radiotherapy }\end{array}$ & OS and DFS \\
\hline Liu et $\mathrm{al}^{16}$ & 2010 & $\begin{array}{l}\text { People's Republic } \\
\text { of China }\end{array}$ & 83 & OscC & I-IV & Surgery & OS \\
\hline Zou et al ${ }^{17}$ & 2010 & $\begin{array}{l}\text { People's Republic } \\
\text { of China }\end{array}$ & 150 & LSCC & I-IV & Surgery & DFS \\
\hline Diniz-Freitas et al ${ }^{18}$ & 2006 & Spain & 47 & Oscc & I-IV & $\begin{array}{l}\text { Surgery and } \\
\text { radiotherapy }\end{array}$ & OS and DFS \\
\hline Hung et $\mathrm{a}^{19}$ & 2006 & $\begin{array}{l}\text { People's Republic } \\
\text { of China }\end{array}$ & 45 & OscC & III-IV & Surgery & OS \\
\hline Kurtz et $\mathrm{a}^{20}$ & 2006 & USA & 45 & HNSCC & I-IV & Surgery & OS and DFS \\
\hline Ueda et $\mathrm{a}^{21}$ & 2006 & Japan & 131 & oscc & I-IV & $\begin{array}{l}\text { Surgery and } \\
\text { chemotherapy }\end{array}$ & DFS \\
\hline Bosch et $\mathrm{a}^{22}$ & 2005 & Germany & $|5|$ & HNSCC & I-IV & Surgery & OS \\
\hline Lim et $\mathrm{al}^{23}$ & 2005 & South Korea & 84 & oscc & I-IV & Surgery & OS \\
\hline Nakanishi et al ${ }^{24}$ & 2004 & Japan & 91 & отSCC & II-IV & Surgery & OS \\
\hline
\end{tabular}

Abbreviations: OS, overall survival; DFS, disease-free survival; OSCC, oral squamous cell carcinoma; DSS, disease-specific survival; LSCC, laryngeal squamous cell carcinoma; HNSCC, head and neck squamous cell carcinoma; PFS, progression-free survival; SCC, squamous cell carcinoma; OTSCC, oral tongue squamous cell carcinoma; NA, not available.

a positive prognostic factor of HNSCC and exhibits better OS or DFS. The reports of Diniz-Freitas et $\mathrm{al}^{18}$ and Kurtz et $\mathrm{al}^{20}$ were also in line with the findings mentioned above. However, Bosch et $\mathrm{al}^{22}$ showed that low E-cadherin gene expression is a positive prognostic factor of HNSCC. In addition, many scholars harbored the idea that E-cadherin gene expression was not an independent prognostic factor of HNSCC. Moreover, most studies included in this metaanalysis $^{6,7,9,11-14,16,17,19,21,24}$ also reported that E-cadherin gene expression was not significantly associated with OS or DFS. The aim of this meta-analysis was retrospective analysis of published literatures to assess the prognostic value of E-cadherin gene expression in patients with HNSCC.

In the present study, we selected 19 studies that were clear regarding not only diagnostic criteria but also inclusion criteria and exclusion criteria. OS and DFS were the primary outcome measures. HR values and their corresponding
$95 \%$ CIs were the statistical indicators to evaluate the impact of E-cadherin gene expression on prognosis of patients with HNSCC.

This meta-analysis confirmed that high E-cadherin gene expression was significantly associated with favorable OS. The HR for OS was 0.57 (95\% CI =0.37, 0.89). However, statistical heterogeneity was obvious, driven by one study. ${ }^{22}$ After sensitivity analysis, heterogeneity became acceptable, and the effect measure was still significant $(\mathrm{HR}=0.52$; $95 \% \mathrm{CI}=0.40,0.66$ ). Differences in immunohistochemical scoring criteria may have contributed to the large heterogeneity between the study by Bosch et al and other included studies. As is known to all, it would make more sense to run a meta-analysis per individual anatomic site rather than lumping together sites that are known for heterogeneity in molecular signature, different standard of care, and different outcomes. Furthermore, the standard of care and outcome 


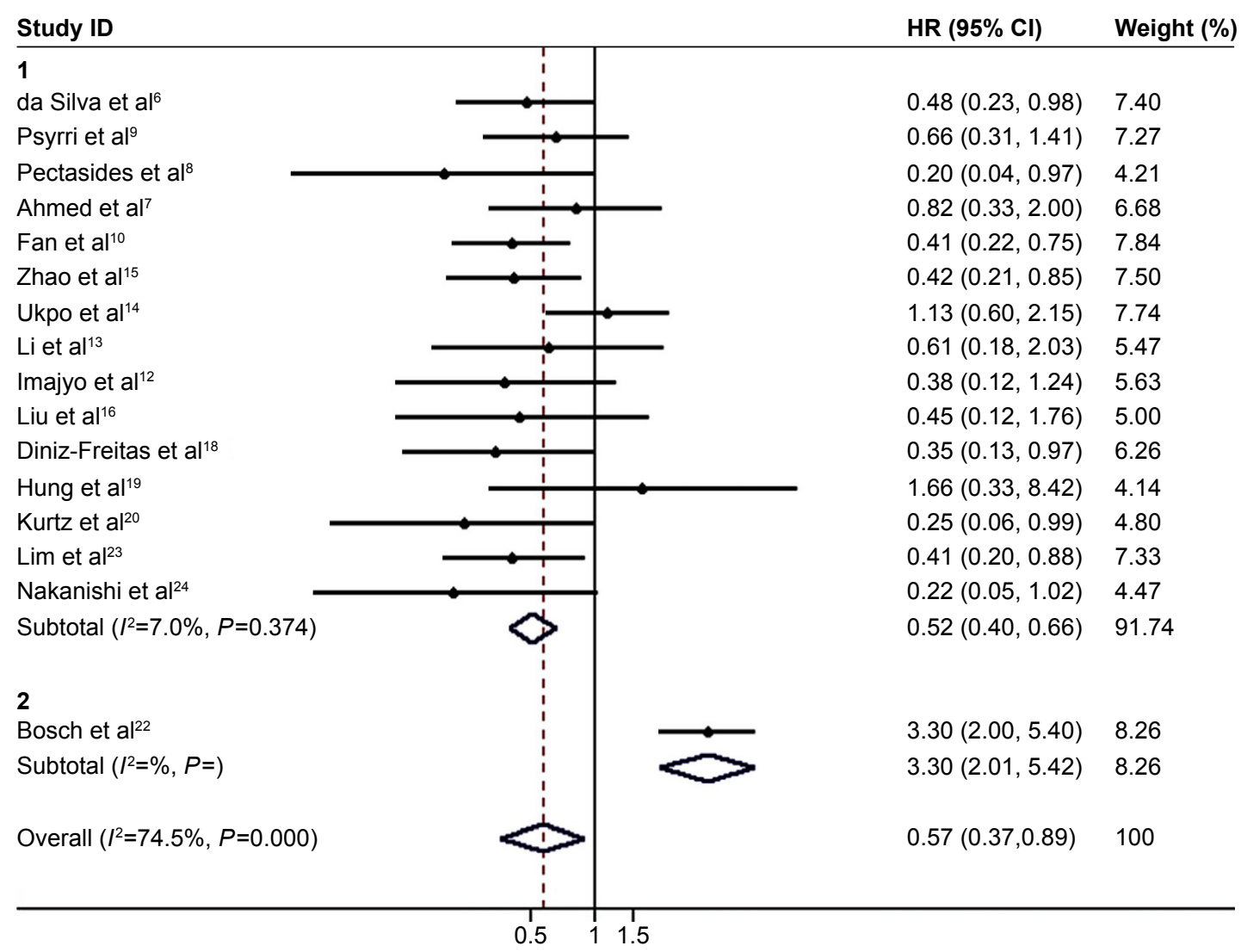

Figure 2 A forest plot for overall survival.

Notes: The difference between the two groups was significant $(\mathrm{HR}=0.57 ; 95 \% \mathrm{Cl}=0.37,0.89 ; P=0.000)$. However, there was great statistical heterogeneity $\left(I^{2}=74.5 \%\right.$, $P=0.000)$. After sensitivity analysis, heterogeneity became acceptable $\left(R^{2}=7.0 \%\right)$ and the effect measure remained significant $(\mathrm{HR}=0.52 ; 95 \% \mathrm{Cl}=0.40,0.66 ; P=0.000)$. "I" means after sensitivity analysis and " $I+2$ " means before sensitivity analysis. Weights are from random effects analysis.

Abbreviations: $\mathrm{HR}$, hazard ratio; $\mathrm{Cl}$, confidence interval.

\begin{tabular}{|c|c|c|}
\hline Study ID & HR (95\% Cl) & Weight (\%) \\
\hline Ahmed et $\mathrm{al}^{7}$ & $0.65(0.29,1.45)$ & 9.03 \\
\hline Psyrri et $\mathrm{al}^{9}$ & $0.51(0.25,1.03)$ & 11.67 \\
\hline Kaur et al ${ }^{11}$ & $0.26(0.10,0.63)$ & 6.91 \\
\hline Imajyo et al ${ }^{12}$ & $0.51(0.29,0.92)$ & 17.56 \\
\hline Li et $\mathrm{al}^{13}$ & $0.69(0.26,1.83)$ & 6.14 \\
\hline Zhao et al ${ }^{15}$ & $0.74(0.42,1.30)$ & 18.33 \\
\hline Zou et al ${ }^{17}$ & $0.52(0.26,1.04)$ & 12.18 \\
\hline Diniz-Freitas et al ${ }^{18}$ & $0.41(0.18,0.95)$ & 8.46 \\
\hline Kurtz et $\mathrm{a}^{20}$ & $0.42(0.10,1.84)$ & 2.76 \\
\hline Ueda et $\mathrm{al}^{21}$ & $0.49(0.20,1.25)$ & 6.97 \\
\hline Overall $\left(I^{2}=0.0 \%, P=0.860\right)$ & $0.53(0.42,0.67)$ & 100 \\
\hline
\end{tabular}

Figure 3 A forest plot for overall survival.

Note: The difference between the high E-cadherin group and the low E-cadherin group was significant $(\mathrm{HR}=0.53 ; 95 \% \mathrm{Cl}=0.42,0.67 ; P=0.000)$ and the heterogeneity was acceptable $\left(I^{2}=0.0 \%, P=0.860\right)$.

Abbreviations: $\mathrm{HR}$, hazard ratio; $\mathrm{Cl}$, confidence interval. 


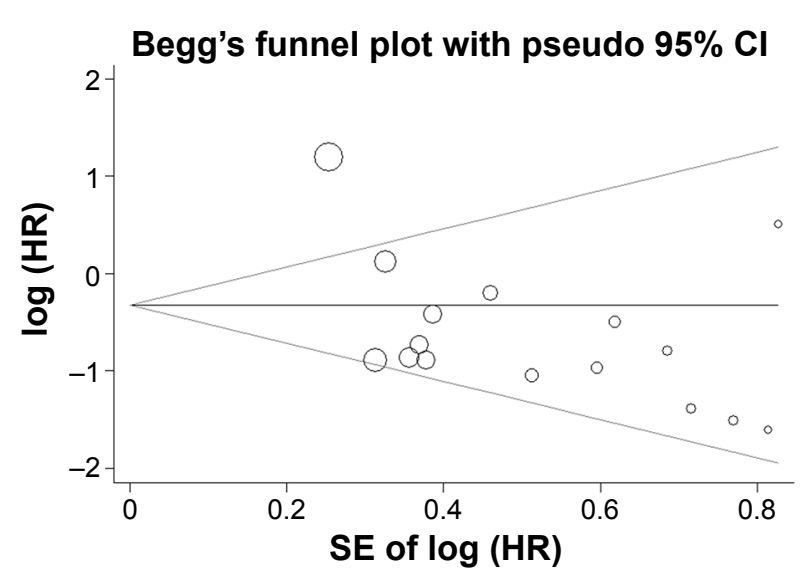

Figure $4 \mathrm{~A}$ funnel plot of meta-analysis of overall survival. Note: According to the funnel plot, there is an asymmetry. Abbreviations: HR, hazard ratio; SE, standard error; $\mathrm{Cl}$, confidence interval.

vary dramatically according to the HNSCC stage; thus, meta-analysis per early versus advanced stage carcinomas would have been much more valuable. Because this study had impeccable protocol and strict inclusion criteria, we did not have the above problems. Moreover, this meta-analysis also confirmed that high E-cadherin gene expression was significantly associated with improved DFS. The HR for DFS was $0.53(95 \% \mathrm{CI}=0.42,0.67)$.

Although a meta-analysis was previously published ${ }^{29}$ that had a similar theme as our study, it was published 3 years ago and therefore did not include over half of the studies included in our meta-analysis. Compared with the study by Zhao et al, we analyzed more outcome measures and included more information than the previous meta-analysis. In addition, based on our judgment, the data extraction and statistical analysis of this meta-analysis by Zhao et al had some small flaws.

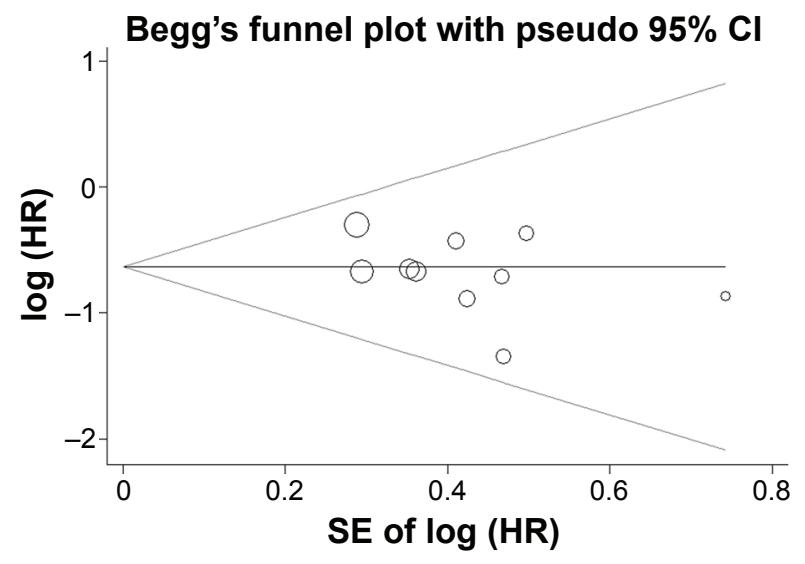

Figure 5 A funnel plot of meta-analysis of disease-free survival. Note: According to the funnel plot, there is an asymmetry. Abbreviations: $\mathrm{HR}$, hazard ratio; SE, standard error; $\mathrm{Cl}$, confidence interval.
Every meta-analysis, including our own, has its internal limitations. ${ }^{31}$ First, all the included studies were retrospective studies, rather than prospective. Additionally, some of these included studies did not provide the HR values and the $95 \%$ CI. We could not directly utilize them for the evaluation of E-cadherin gene expression and OS, and had to calculate HR values and their $95 \% \mathrm{CI}$ according to the data provided by the researchers. Owing to various reasons, the results may have deviated slightly. Also, there was obvious heterogeneity among these studies. Additionally, selective reporting of individual research also limited this meta-analysis. Owing to various reasons, obtaining all data for a complete review of E-cadherin gene in HNSCC is impossible. To resolve these problems, we calculated HR values and their 95\% CI according to reported methods. ${ }^{26}$ This allowed us to increase the sample size for this study and make the findings more reliable. All these factors might affect the outcomes measured and might have influenced the findings. More studies with better designed criteria are required to further confirm our results.

\section{Conclusion}

In conclusion, this meta-analysis showed clear evidence that high E-cadherin gene expression is a positive prognostic factor of HNSCC and is associated with better OS and DFS. However, some limitations weakened the power of this meta-analysis, and the conclusions should be interpreted with caution.

\section{Disclosure}

The authors report no conflicts of interest in this work.

\section{References}

1. Jemal A, Bray F, Center MM, Ferlay J, Ward E, Forman D. Global cancer statistics. CA Cancer J Clin. 2011;61:69-90.

2. Ren ZH, Xu JL, Fan TF, Ji T, Wu HJ, Zhang CP. The harmonic scalpel versus conventional hemostasis for neck dissection: a meta-analysis of the randomized controlled trials. PLoS One. 2015;10:e132476.

3. Silverman S Jr. Demographics and occurrence of oral and pharyngeal cancers. The outcomes, the trends, the challenge. J Am Dent Assoc. 2001; 132(suppl):7S-11S.

4. Chandler K, Vance C, Budnick S, Muller S. Muscle invasion in oral tongue squamous cell carcinoma as a predictor of nodal status and local recurrence: just as effective as depth of invasion? Head Neck Pathol. 2011;5: 359-363.

5. Ren $\mathrm{ZH}, \mathrm{Wu} \mathrm{HJ}$, Zhang S, et al. A new surgical strategy for treatment of tongue squamous cell carcinoma based on anatomic study with preliminary clinical evaluation. J Craniomaxillofac Surg. 2015;43: $1577-1582$.

6. da Silva SD, Morand GB, Alobaid FA, et al. Epithelial-mesenchymal transition (EMT) markers have prognostic impact in multiple primary oral squamous cell carcinoma. Clin Exp Metastasis. 2015;32:55-63.

7. Ahmed RA, Shawky Ael A, Hamed RH. Prognostic significance of cyclin D1 and E-cadherin expression in laryngeal squamous cell carcinoma. Pathol Oncol Res. 2014;20:625-633. 
8. Pectasides E, Rampias T, Sasaki C, et al. Markers of epithelial to mesenchymal transition in association with survival in head and neck squamous cell carcinoma (HNSCC). PLoS One. 2014;9:e94273.

9. Psyrri A, Kotoula V, Fountzilas E, et al. Prognostic significance of the Wnt pathway in squamous cell laryngeal cancer. Oral Oncol. 2014;50: 298-305.

10. Fan CC, Wang TY, Cheng YA, et al. Expression of E-cadherin, twist, and p53 and their prognostic value in patients with oral squamous cell carcinoma. J Cancer Res Clin Oncol. 2013;139:1735-1744.

11. Kaur J, Sawhney M, DattaGupta S, et al. Clinical significance of altered expression of beta-catenin and E-cadherin in oral dysplasia and cancer: potential link with ALCAM expression. PLoS One. 2013;8:e67361.

12. Imajyo I, Sugiura T, Kobayashi Y, et al. T-box transcription factor Brachyury expression is correlated with epithelial-mesenchymal transition and lymph node metastasis in oral squamous cell carcinoma. Int J Oncol. 2012;41:1985-1995.

13. Li JJ, Zhang GH, Yang XM, et al. Reduced E-cadherin expression is associated with lymph node metastases in laryngeal squamous cell carcinoma. Auris Nasus Larynx. 2012;39:186-192.

14. Ukpo OC, Thorstad WL, Zhang Q, Lewis JS Jr. Lack of association of cadherin expression and histopathologic type, metastasis, or patient outcome in oropharyngeal squamous cell carcinoma: a tissue microarray study. Head Neck Pathol. 2012;6:38-47.

15. Zhao D, Tang XF, Yang K, Liu JY, Ma XR. Over-expression of integrinlinked kinase correlates with aberrant expression of Snail, E-cadherin and N-cadherin in oral squamous cell carcinoma: implications in tumor progression and metastasis. Clin Exp Metastasis. 2012;29:957-969.

16. Liu LK, Jiang XY, Zhou XX, Wang DM, Song XL, Jiang HB. Upregulation of vimentin and aberrant expression of E-cadherin/beta-catenin complex in oral squamous cell carcinomas: correlation with the clinicopathological features and patient outcome. Mod Pathol. 2010;23: 213-224.

17. Zou J, Yang H, Chen F, et al. Prognostic significance of fascin-1 and E-cadherin expression in laryngeal squamous cell carcinoma. Eur J Cancer Prev. 2010;19:11-17.

18. Diniz-Freitas M, Garcia-Caballero T, Antunez-Lopez J, Gandara-Rey JM, Garcia-Garcia A. Reduced E-cadherin expression is an indicator of unfavourable prognosis in oral squamous cell carcinoma. Oral Oncol. 2006;42:190-200.

19. Hung KF, Chang CS, Liu CJ, Lui MT, Cheng CY, Kao SY. Differential expression of E-cadherin in metastatic lesions comparing to primary oral squamous cell carcinoma. J Oral Pathol Med. 2006;35:589-594.
20. Kurtz KA, Hoffman HT, Zimmerman MB, Robinson RA. Decreased E-cadherin but not beta-catenin expression is associated with vascular invasion and decreased survival in head and neck squamous carcinomas. Otolaryngol Head Neck Surg. 2006;134:142-146.

21. Ueda G, Sunakawa H, Nakamori K, et al. Aberrant expression of beta- and gamma-catenin is an independent prognostic marker in oral squamous cell carcinoma. Int J Oral Maxillofac Surg. 2006;35:356-361.

22. Bosch FX, Andl C, Abel U, Kartenbeck J. E-cadherin is a selective and strongly dominant prognostic factor in squamous cell carcinoma: a comparison of E-cadherin with desmosomal components. Int J Cancer. 2005;114:779-790.

23. Lim J, Kim JH, Paeng JY, et al. Prognostic value of activated Akt expression in oral squamous cell carcinoma. J Clin Pathol. 2005;58: 1199-1205.

24. Nakanishi Y, Akimoto S, Sato Y, Kanai Y, Sakamoto M, Hirohashi S. Prognostic significance of dysadherin expression in tongue cancer: immunohistochemical analysis of 91 cases. Appl Immunohistochem Mol Morphol. 2004;12:323-328.

25. Takeichi M. Cadherin cell adhesion receptors as a morphogenetic regulator. Science. 1991;251:1451-1455.

26. Tierney JF, Stewart LA, Ghersi D, Burdett S, Sydes MR. Practical methods for incorporating summary time-to-event data into meta-analysis. Trials. 2007;8:16.

27. Jamieson NB, Carter CR, McKay CJ, Oien KA. Tissue biomarkers for prognosis in pancreatic ductal adenocarcinoma: a systematic review and meta-analysis. Clin Cancer Res. 2011;17:3316-3331.

28. Gould Rothberg BE, Bracken MB. E-cadherin immunohistochemical expression as a prognostic factor in infiltrating ductal carcinoma of the breast: a systematic review and meta-analysis. Breast Cancer Res Treat. 2006;100:139-148.

29. Zhao Z, Ge J, Sun Y, et al. Is E-cadherin immunoexpression a prognostic factor for head and neck squamous cell carcinoma (HNSCC)? A systematic review and meta-analysis. Oral Oncol. 2012;48: 761-767.

30. Luo SL, Xie YG, LiZ, Ma JH, Xu X. E-cadherin expression and prognosis of oral cancer: a meta-analysis. Tumour Biol. 2014;35:5533-5537.

31. Ren ZH, Xu JL, Li B, Fan TF, Ji T, Zhang CP. Elective versus therapeutic neck dissection in node-negative oral cancer: evidence from five randomized controlled trials. Oral Oncol. 2015;51:976-981.
OncoTargets and Therapy

\section{Publish your work in this journal}

OncoTargets and Therapy is an international, peer-reviewed, open access journal focusing on the pathological basis of all cancers, potential targets for therapy and treatment protocols employed to improve the management of cancer patients. The journal also focuses on the impact of management programs and new therapeutic agents and protocols on

\section{Dovepress}

patient perspectives such as quality of life, adherence and satisfaction. The manuscript management system is completely online and includes a very quick and fair peer-review system, which is all easy to use. Visit http://www.dovepress.com/testimonials.php to read real quotes from published authors. 